DOI https://doi.org/10.15589/znp2020.3(481).5

УДК 621.438

\title{
INCREASING ENERGY EFFICIENCY OF NATURAL GAS REDUCTION DUE TO USE OF ROTARY PISTON ENGINES
}

\section{ПІДВИЩЕННЯ ЕНЕРГОЕФЕКТИВНОСТІ РЕДУКУВАННЯ ПРИРОДНОГО ГАЗУ ЗАВДЯКИ ВИКОРИСТАННЮ РОТОРНО-ПОРШНЕВИХ ДВИГУНІВ}

\author{
Oleksandr. S. Mytrofanov \\ mitrofanov.al.ser@gmail.com \\ ORCID: 0000-0003-3460-5369 \\ Arkadii Yu. Proskurin \\ arkadii.proskurin@nuos.edu.ua \\ ORCID: 0000-0002-5225-6767
}

\author{
О. С. Митрофанов, \\ канд. техн. наук, доцент
}

А. Ю. Проскурін,

канд. техн. наук, доцент

\author{
Admiral Makarov National University of Shipbuilding, Mykolaiv \\ Національний університет кораблебудування імені адмірала Макарова, м. Миколаїв
}

\begin{abstract}
Purpose. Evaluate the efficiency of using a new design rotary piston engine as a utilizer of natural gas excess pressure energy during its reduction in gas transportation and gas distribution systems.

Method. To study the processes of energy utilization of excess pressure of natural gas during its reduction in gas transportation and gas distribution systems using rotary piston expansion machines of a new design, it is advisable to use the method of mathematical modeling. The mathematical model takes into account the main features of the new design of the expansion machine and is adequate, since it accurately reflects the main processes occurring in the working cylinder.

Results. A study of the efficiency of utilization of the energy potential of compressed natural gas is carried out for an automated gas distribution station designed to power one consumer of GDS-5 frame size (nominal consumption of natural gas is $5000 \mathrm{Nm} 3 / \mathrm{h}$, inlet pressure is $1,2 \ldots .5,5 \mathrm{MPa}$, outlet pressure is $0,003 \ldots 1,2 \mathrm{MPa}$ ).

A schematic diagram of an automated gas distribution station using utilization expander generators of electric current is proposed. $20 \mathrm{RPD}-7.5 / 5.89$ rotary piston engine is used as an expansion machine, which, due to its design, combines the advantages of volumetric and kinetic expanders and, accordingly, effectively operates at various parameters of the working fluid. This allows to expand the scope of the expander application and unify the equipment.

Expander-generators are placed in the reduction point parallel to the main and reserve natural gas reduction lines, which allows to optimize the operation of the gas distribution station in all operating modes (pressure and consumption rates of natural gas). So, depending on pressure $(1,2 \ldots 5,5 \mathrm{MPa})$ and flow $\left(5500 \ldots 2200 \mathrm{Nm}^{3} / \mathrm{h}\right)$ of natural gas, the effective power of the rotary piston engine is $132 \ldots 29 \mathrm{~kW}$. Due to its design features (no dead volume, the ability to adjust the valve timing and engine operating modes due to the degree of cylinder filling) 20 RPD-7.5/5.89 rotary piston engine provides high specific effective consumption of natural gas. So, depending on the operating mode of the expander generator, the consumption of natural gas varies between $34,4 \ldots 56,7 \mathrm{~kg} / \mathrm{kW} \cdot \mathrm{h}$.

Scientific novelty. Indicator diagrams are given for different values of pressure of natural gas at the inlet to the rotary piston engine. The dependences of changes in the effective and operational parameters of the expander-generator power plant are given.

Practical importance. The volumes of utilized energy of compressed natural gas for an automated gas distribution station with an average monthly flow rate of $0,6 \ldots 3,3$ million $\mathrm{m}^{3}$ were estimated. The monthly energy generation, depending on the consumption, ranges from 9 to $89 \mathrm{MW}$.
\end{abstract}

Key words: expander generator; natural gas; gas distribution station; rotary piston engine; gas reduction; effective and operational parameters.

Анотація. Мета. Оцінка ефективності застосування роторно-поршневих двигунів нової конструкції як утилізатора енергії надлишкового тиску природного газу під час його редукування в газотранспортних та газорозподільних системах.

Методика. Для дослідження процесів утилізації енергії надлишкового тиску природного газу під час його редукування в газотранспортних та газорозподільних системах із використанням роторно-поршневих 


\section{ЕНЕРГЕТИЧНЕ МАШИНОБУДУВАННЯ №3-2020}

розширювальних машин нової конструкції доцільно використовувати метод математичного моделювання. Математична модель ураховує основні особливості нової конструкції розширювальної машини та є адекватною, оскільки досить точно відображає основні процеси в робочому циліндрі.

Результати. Дослідження ефективності утилізації енергетичного потенціалу стиснутого природного газу виконано для автоматизованої газорозподільної станції, розрахованої на живлення одного споживача типорозміру ГРС-5 (номінальна витрата природного газу становить 5000 Нм3/ч, тиск на вході - 1,2...5,5 МПа, на виході - 0,003...1,2 МПа).

Запропоновано принципову схему автоматизованої газорозподільної станції з використанням утилізаційних детандер-генераторів електричного струму. Як розширювальна машина використовується роторно-поршневий двигун 20 РПД-7,5/5,89, який завдяки своїй конструкції об’єднує переваги детандерів об'ємної й кінетичної дії, ефективно працює за різних параметрів робочого тіла. Це дозволяє розширити межі застосування детандерів і уніфікувати обладнання.

Детандер-генератори розміщуються в пункті редукування паралельно основній та резервній нитці редукування природного газу, що дає змогу оптимізувати роботу газорозподільної станції на всіх експлуатаційних режимах (значення тиску та витрати природного газу). Так, залежно від тиску (1,2..5,5 МПа) та витрати (5 500...2 $200 \mathrm{Hм}^{3} /$ год) природного газу ефективна потужність роторно-поршневого двигуна становить $132 \ldots 29$ кВт. Завдяки своїм конструктивним особливостям (відсутність мертвого об’єму, можливість регулювання фаз газорозподілу та режимів роботи двигуна завдяки ступеню наповнення циліндра) роторно-поршневий двигун 20 РПД-7,5/5,89 забезпечує високі показники питомої ефективної витрати природного газу. Так, залежно від режиму роботи детандер-генератора витрати природного газу змінюються і межах 34,4 ...56,7 кг/кВт·год.

Наукова новизна. Індикаторні діаграми за різних значень тиску природного газу на вході в роторно-поршневий двигун. Подано залежності зміни ефективних і експлуатаційних показників детандер-генераторної енергетичної установки.

Практична значимість. Проведена оцінка об’ємів утилізованої енергії стиснутого природного газу для автоматизованої газорозподільної станції із середньою місячною витратою $0,6 \ldots 3,3$ мільйони м³. Щомісячна генерація енергії залежно від витрати становить від 9 до 89 МВт.

Ключові слова: детандер-генератор; природний газ; газорозподільна станція; роторно-поршневий двигун; редукування газу; ефективні й експлуатаційні показники.

\section{FORMULATION OF THE PROBLEM}

Currently, in fuel and energy balance of the world developed countries, there is a redistribution of the use of the main types of extracting energy resources, namely oil, coal and natural gas [1-3]. So, the share of using natural gas in various industries and in everyday life is growing more and more. The use of natural gas as a fuel in transport power plants (road, rail and ship) has been especially intensively developed. The increase in the share of natural gas in the energy balance is primarily due to its consumer properties (ease of maintenance of gas equipment, high temperature, full combustion, more accurate temperature control during combustion), lower price (due to very significant world reserves and low production costs) and environmental friendliness (the lowest $\mathrm{CO}_{2}$ carbon dioxide emissions from combustion compared to petroleum products and coal).

The final cost of natural gas is determined by many factors, from the degree of complexity of gas production technology to preparation and transportation. So, natural gas is transported using pipelines and gas tankers in which gas is transported in a liquefied state (LNG). Transportation of natural gas by sea (for example, to the Japanese market) is more expensive, since it is necessary to spend additional energy to liquefy natural gas. Therefore, the direction of research in the field of regeneration of the energy expended for the compression of natural gas is very relevant and is gaining more and more intensive development.

\section{ANALYSIS OF RECENT RESEARCH AND PUBLICATIONS}

Reducing the final cost of natural gas directly depends on the efficiency of the preparation and transportation systems, and the utilization of the energy of excess gas pressure during its reduction is a promising area of research. Compressed natural gas contains significant potential of useful energy, which in most cases is not used. However, if expander generators are used instead of conventional throttling devices, this will partially recover the energy spent on natural gas compression [4]. Thus, using expander generators, it is possible to generate environmentally friendly electricity and use the effect of gas cooling during expansion in refrigeration plants.

Recently, the use of expander generators of electrical energy for the utilization of compressed natural gas energy has received comprehensive development. So, the expander generators have found their application in heat power engineering, namely at thermal power plants and urban boiler houses [5-7]. Expanders are widely used in gas distribution stations, gas supply systems and industry [8-10]. In connection with rather intensive development of the LNG market $[11 ; 12]$, a promising direction for the use of expander generators is also their use in power plants for the utilization of cold during regasification $[13 ; 14]$. 


\section{SEPARATION OF PREVIOUSLY UNSOLVED PARTS OF THE OVERALL PROBLEM}

Expanders are used to reduce the pressure in the adiabatic process, while at the end we get mechanical energy and cooling of the working fluid. Like pumps, expanders can be divided according to the principle of operation into volumetric and kinetic expansion machines. So, in the volumetric expanders, the expansion of the working fluid (that is, a change in the working volume) takes place, and in the engines of kinetic action (Turboexpanders), energy is converted due to the interaction of the flow of the working fluid with the blades of the impeller. It is generally accepted that piston (volumetric) expanders are used at low costs of the working fluid and high inlet pressures, and turboexpanders are used at low pressures and high flow rates of the working fluid. This separation is clearly influenced by the expander design and, accordingly, the energy conversion efficiency.

The unification and expansion of the boundaries of the use of expanders in power plants for the preparation, transportation and distribution of natural gas is a very promising and demanded area of research.

\section{THE AIM OF THE STUDY}

The aim of the research is to evaluate the efficiency of using a new design rotary piston engine as a utilizer of natural gas excess pressure energy during its reduction in gas transportation and gas distribution systems.

\section{METHODS, OBJECT AND SUBJECT OF THE RESEARCH}

To study the processes of energy utilization of excess pressure of natural gas during its reduction in gas transportation and gas distribution systems using rotary piston expansion machines of a new design, it is advisable to use the method of mathematical modeling. So mathematical modeling of a complex technical system will allow to get a preliminary assessment of its effectiveness without large financial, resource and time costs. To achieve this goal, a developed and software-implemented mathematical model of the working cycle of a rotary piston engine is used, based on the fundamental equations of thermodynamics, gas dynamics, heat and mass transfer. The mathematical model takes into account the main features of the new design of the expansion machine and is adequate, since it accurately reflects the main processes occurring in the working cylinder.

The object of the research is the processes of converting the energy of excess pressure of natural gas during expansion in a rotary piston expander. The subject of the study is the laws and parameters of the processes of energy conversion of compressed natural gas in a rotary piston engine.

\section{THE MAIN MATERIAL}

From the places of production or storage and to the final consumer, natural gas is transported under high pressure using the main pipelines of the gas supply system. Gas distribution stations (GDS) and points (GDP) are components of a general gas supply system and are a complex technical system with increased requirements for reliability and safety. The main task of GDS is to reduce gas pressure in accordance with the needs of consumer. Typically, for gas distribution stations, the initial pressure is $7,5 \ldots .5,5 \mathrm{MPa}$, the final pressure is $1,2 \ldots 0,6 \mathrm{MPa}$, and for GDP, respectively, 1,2 $\mathrm{MPa}$ and $0,3 \ldots 0,1 \mathrm{MPa}[5 ; 15]$. Commonly, pressure decrease occurs due to the reduction by one or two stages, while the energy potential of the high gas pressure is lost without loss of physical heat of combustion. In modern gas transportation systems, the energy potential of compressed natural gas is used in utilizers (turboexpanders or piston expanders). Operational characteristics that directly depend on the design of the utilizer determine its use for the corresponding parameters of natural gas (pressure and flow), which makes unification difficult. The rotary piston engine developed by Motor-Plus LLC, the machine-building enterprise (Ukraine, Mykolaiv), constructively combines the advantages of both types of expansion machines, and can be used quite effectively for various parameters of the working fluid (inlet pressure and flow rate).

Fig. 1 shows a generalized scheme of an automated gas distribution station with the utilization of excess natural gas pressure through the use of new design rotary piston engines. Expander generators are placed in a natural gas reduction point parallel to the main and reserve reduction lines. This allows to optimize the operation of GDS in all operating modes.

To conduct researches on the efficiency of using a rotary piston engine as a utilizer of natural gas excess pressure, an automated gas distribution station was designed as a basis for supplying a single consumer of GDS-5 frame size [15]. The basic GDS-5 is designed to reduce and maintain a given gas pressure at the outlet at the required flow rate for household and industrial consumers. GDS also provides pre-treatment of natural gas (purification and odorization) and measurement of its consumption. The main technical characteristics of the gas distribution station GDS-5 are shown in Table 1 [15].

The 20 RPD-7.5/5.89 rotary piston engine (Fig. 2) is used as part of an electric current expander generator, the main parameters of which are presented in table 2.

The rotary piston engine has 20 cylinders placed evenly at an angle of $18^{\circ}$ towards the central control cam. This arrangement of the cylinders is guaranteed to start the engine in any position. The ratio of the piston stroke $S$ to the cylinder diameter $D$ is $S / D=0,78$, which makes it possible to ensure low values of the average piston speed, thereby reducing gas-dynamic losses at the intake and exhaust strokes, as well as reducing the dimensions of the engine.

Depending on the operating mode of the gas distribution system (parameters of natural gas at the inlet), 


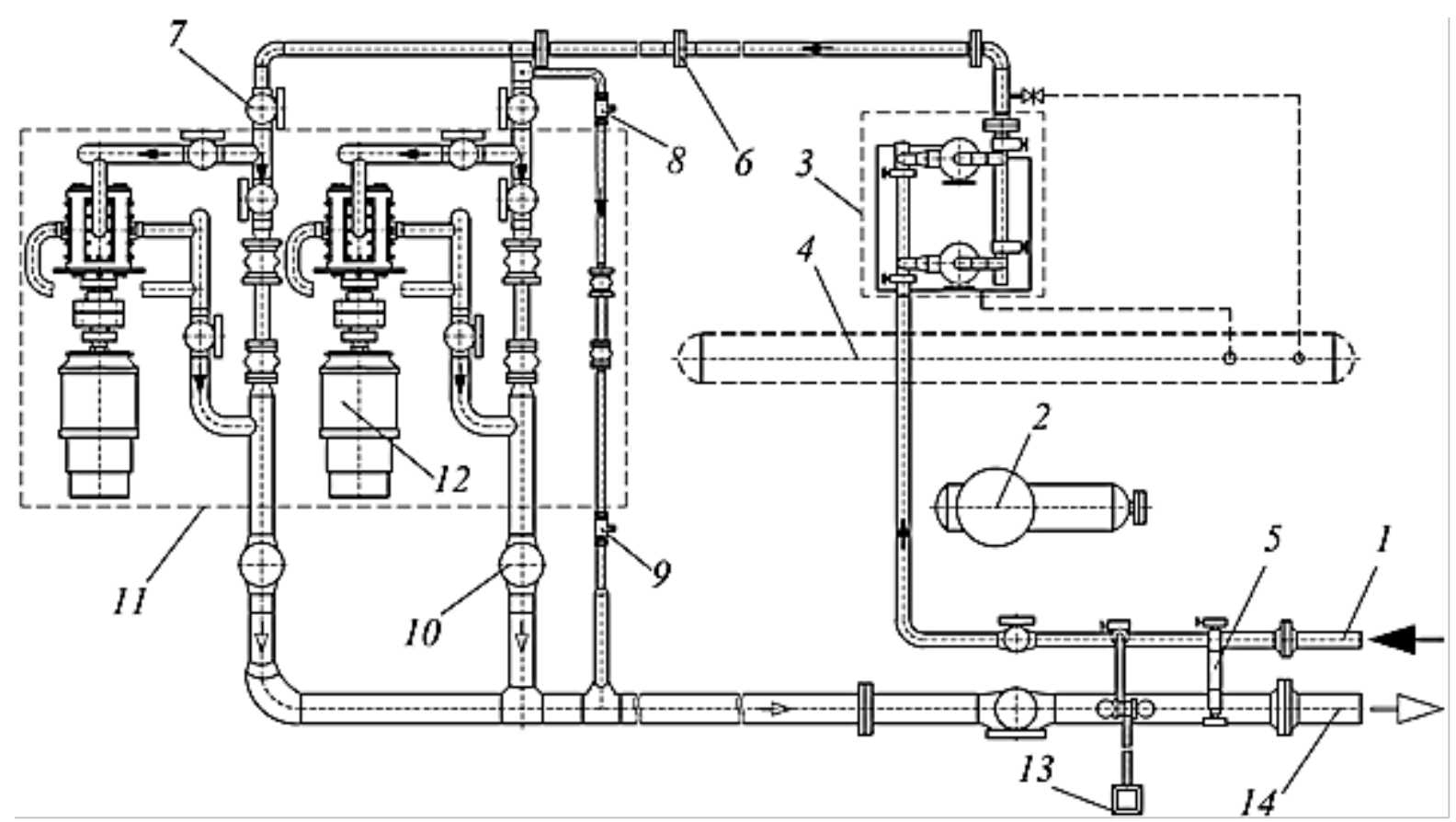

Fig. 1. General scheme of an automated gas distribution station with utilization of excess natural gas pressure: 1 - natural gas supply pipeline from the main pipeline; 2 - odorization unit; 3 - gas purification unit; 4 - condensate collection unit; 5 - shutdown unit; 6 - gas flow rate measuring device; 7, 8, 9- through-plug cork valve made of carbon steel with ends for welding; 10 - ball valve made of carbon steel with ends for welding and manual mechanical drive; 11 - point for reduction and utilization of excess pressure of natural gas; 12 - rotary piston expander generator; 13 - spark plug; 14 - low pressure outlet pipeline

Table 1. Main technical and operational characteristics of GDS-5 gas distribution station

\begin{tabular}{|c|c|c|c|}
\hline № & Parameter & Unit & Value \\
\hline 1. & Working body & - & Natural gas \\
\hline 2. & Nominal consumption & $\mathrm{Nm}^{3} / \mathrm{h}$ & 5000 \\
\hline 3. & Inlet gas pressure & $\mathrm{MPa}$ & $1,2 \ldots 5,5$ \\
\hline 4. & Outlet gas pressure & $\mathrm{MPa}$ & $0,003 \ldots 1,2$ \\
\hline 5. & Ambient temperature & - & $-50 \ldots+45$ \\
\hline 6. & Deviation from the set outlet pressure & - & $\pm 2,5 \%$ \\
\hline 7. & GDS implementation & $\mathrm{m}$ & 3,000 \\
\hline & Overall dimensions: & & 2,990 \\
8. & - length; & & 2,375 \\
\hline
\end{tabular}

Table 2. The main parameters of the 20 RPD-7.5/5.89 rotary piston engine

\begin{tabular}{|c|c|c|c|}
\hline № & Parameter & Unit & Value \\
\hline 1. & Diameter of working cylinder & $\mathrm{mm}$ & 75 \\
\hline 2. & Piston stroke & $\mathrm{mm}$ & 58,9 \\
\hline 3. & S/D ratio & - & 0,78 \\
\hline 4. & Number of cylinders & - & 20 \\
\hline 5. & Engine displacement & $\mathrm{cm}^{3}$ & 5207 \\
\hline 6. & $\begin{array}{c}\text { Relative dead volume } \\
\text { (technological) }\end{array}$ & - & 0,013 \\
\hline
\end{tabular}

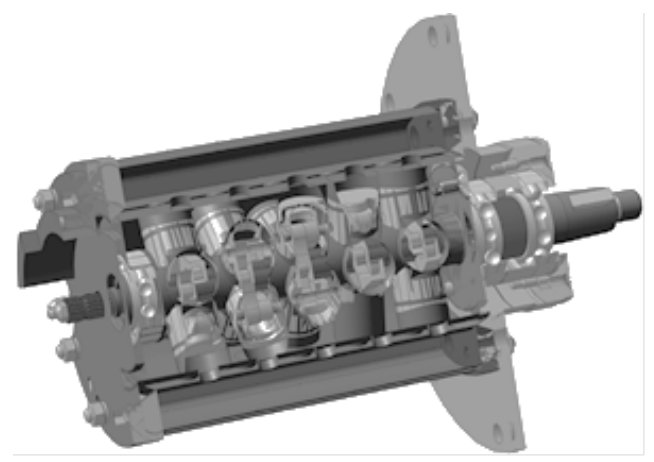

Fig. 2. 20 RPD-7.5/5.89 rotary piston engine 


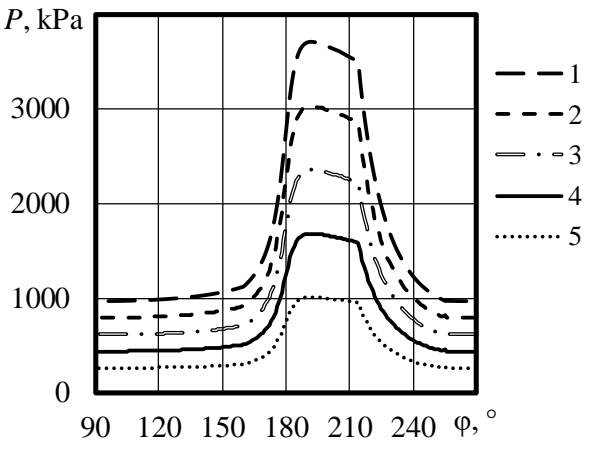

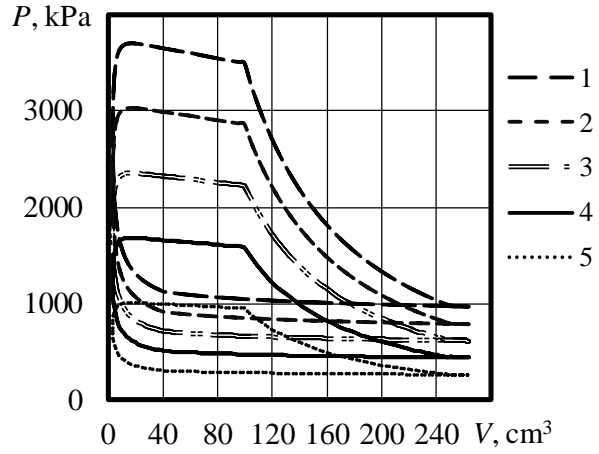

$\mathrm{b}$

Fig. 3. Indicator diagrams of various operating modes of the 20 RPD-7.5/5.89 rotary piston expander: $a$ - detailed; $b-$ minimized; $1-N_{e}=132 \mathrm{~kW} ; 2-N_{e}=108 \mathrm{~kW} ; 3-N_{e}=84 \mathrm{~kW}$; $4-N_{e}=60 \mathrm{~kW} ; 5-N_{e}=36 \mathrm{~kW}$

the control of the rotary piston engine was ensured by changing the degree of cylinder filling (the ratio of the volume of the working cylinder of the engine at the time of filling to the full volume), which made it possible to achieve the maximum efficiency of utilization of the energy of compressed natural gas. Fig. 3 shows the detailed and minimized indicator charts, and Fig. 4 the change in the effective expander generator performance in various operating modes. The rotary piston engine worked according to the load characteristic when the gas pressure in the pressure line changed between $1,2 \ldots 5,5 \mathrm{MPa}$, while the effective power of the rotary piston engine varied within $132 \ldots 29 \mathrm{~kW}$. The average piston speed of the engine was $C_{m}=1,178 \mathrm{~m} / \mathrm{s}$, which significantly reduces the pressure loss of natural gas during filling and reduces the resistance during release.

The greatest influence on the effective performance of the engine is the absence of dead volume (the value of the relative dead volume of the engine, which is due only to the technological gaps during manufacture, is only 0,013 ) and the possibility of regulating the degree of filling of the working cylinder within a fairly wide range $(0,13 \ldots 0,5)$. So, at the nominal operating mode, the specific consumption of the working fluid is $34,4 \mathrm{~kg} / \mathrm{kW} \cdot \mathrm{h}$, which is much lower than similar analogue engines.

Due to its design features, the rotary piston engine allows for low values of the specific effective energy consumption of compressed natural gas (i.e. maximum utilization).

For the possible use of rotary piston engines as part of the expander generator utilization power plants of automated gas distribution stations, it is necessary to ensure coordination of the technical and operational parameters of expander and gas distribution system. Moreover, the expander generator must ensure the maximum utilization of compressed natural gas energy in all operating modes of the gas distribution station without reducing its efficiency. Fig. 5 shows the dependences of the change in the main technical and operational parameters of the 20 RPD-7.5/5.89 rotary piston expander, depending on the pressure of natural gas in the supply main pipeline $(1,2 \ldots 5,5 \mathrm{MPa})$. From the presented dependences it can be seen that the expander generator provides the required values of pressure and flow rate of natural gas at the outlet (5 $500 \ldots 2200 \mathrm{Nm}^{3} / \mathrm{h}$ ).

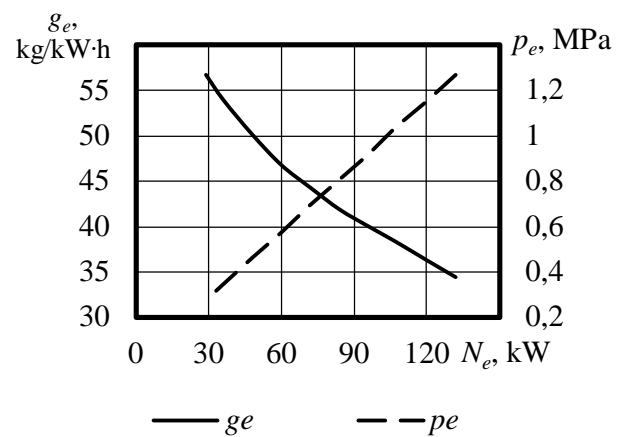

Fig. 4. Change in effective indicators of the $20 \mathrm{RPD}-7,5 / 5,89$ rotary piston expander

Depending on the consumer category (household, utilities, industrial, etc.), the annual consumption of natural gas can be millions of $\mathrm{m}^{3}$. Moreover, any consumption group uses a different amount of gas every month. This is primarily due to climatic conditions, production workload and operating hours of industrial enterprises, etc. Accordingly, the amount of utilized energy potential of compressed natural gas will vary depending on the consumer and the month of the year. Fig. 6 shows the possible amount of utilized energy during gas reduction for various categories of consumers, depending on the monthly load (statistical data on natural gas consumption in accordance with [15]).

Thus, in accordance with Fig. 6, the use of rotary piston expanders for utilization during reduction at an automated gas distribution station with a monthly natural gas consumption of $0,6 \ldots 3300000 \mathrm{~m}^{3} /$ month allows to 

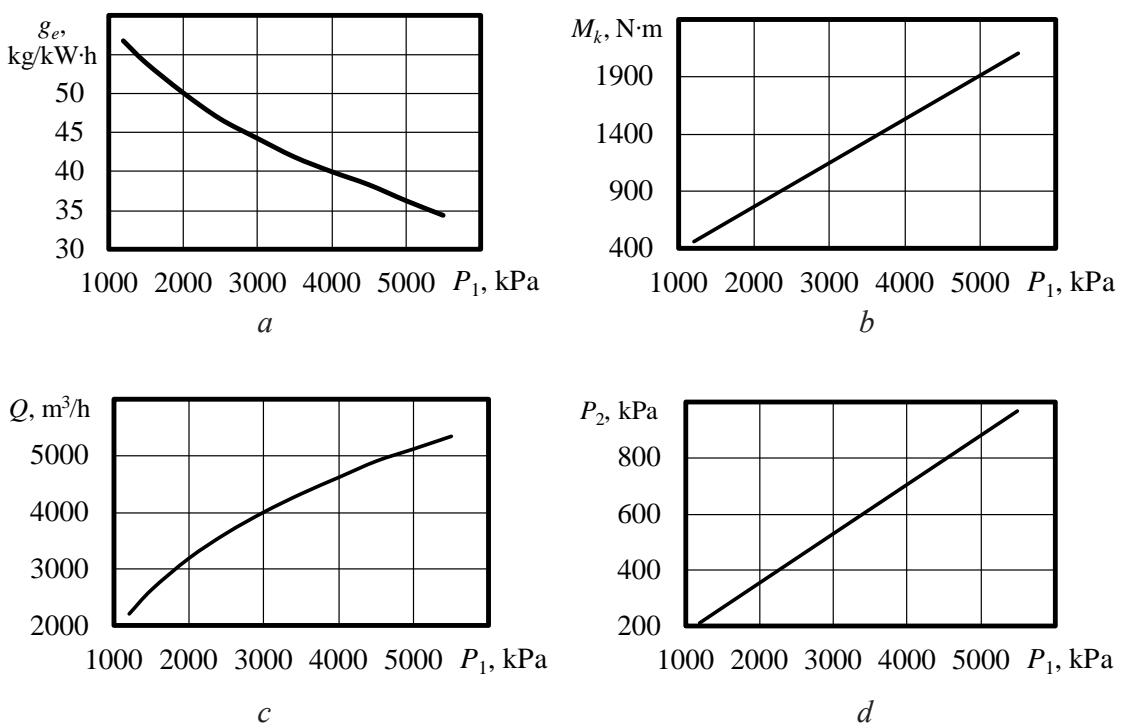

Fig. 5. The operational characteristics of the expander generator depending on the inlet natural gas pressure: $a$-specific effective consumption of natural gas; $b$-torque; $c$-normal time consumption of natural gas; $d$ - outlet natural gas pressure of the expander generator (after disposal)

regenerate from 9 to $89 \mathrm{MW}$ of energy every month. The generated energy can be used both to provide services for the GDS own needs, and for other industrial or household consumers.

\section{DISCUSSION OF THE OBTAINED RESULTS}

The proposed scheme of an automated gas distribution station using new-design rotary piston engines for reducing expander generators allows not only to provide the necessary parameters of natural gas at the outlet (pressure and flow rate), but also to utilize the energy potential of the compressed gas flow. Thus, the material costs for the modernization of existing ones or design and creation of new gas distribution stations with utilization system will quickly pay off due to received environmentally friendly energy.

The amount of utilized energy (i.e. specific effective consumption of natural gas) directly depends on the excellence of the expander. Therefore, increasing the effective indicators of a rotary piston engine and studying their changes from the parameters of the working process and the design features of the engine is a further promising direction of research.

As a result of sharp expansion of natural gas in the working cylinder, not only the pressure but also the temperature decreases. A decrease in gas temperature also occurs during inlet and outlet. Low temperatures can adversely affect the operation of the expander (especially for the lubrication system), so this issue also requires separate consideration and research. A solution to this problem may be, for example, preheating the working fluid before expansion in the expander or deeper utilization of the cold in the refrigeration complex.

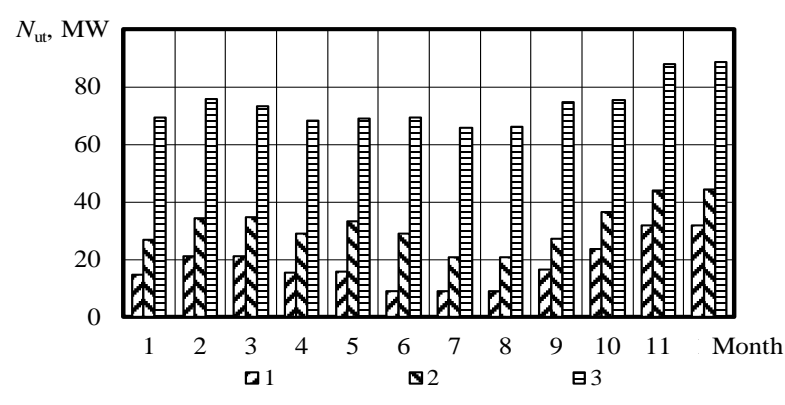

Fig. 6. Annual utilization of energy of compressed natural gas during reduction: 1 - household use; 2 - melting furnaces; 3 - industrial ovens

\section{CONCLUSIONS}

1. A schematic diagram of an automated gas distribution station with the utilization of compressed natural gas energy is proposed. $20 \mathrm{RPD}-7.5 / 5.89$ new design rotarypiston engine is used as a gas excess pressure utilizer. The dependences of changes in the effective and technical and operational indicators of the expander generator plant, as well as indicator diagrams of the engine at different values of the natural gas pressure at the inlet, are presented and analyzed.

2. It is defined that, depending on the parameters of natural gas (gas pressure is $1,2 \ldots .5,5 \mathrm{MPa}$ and flow rate is $5500 \ldots 2200 \mathrm{Nm}^{3} / \mathrm{h}$ ), the effective power at the inlet to the rotary piston engine is $132 \ldots 29 \mathrm{~kW}$, and specific effective fuel consumption is $34,4 \ldots 56,7 \mathrm{~kg} / \mathrm{kW} \cdot \mathrm{h}$.

3. It was determined that with an average monthly use of natural gas in the range of $0.6 \ldots 3300000 \mathrm{~m}^{3} / \mathrm{month}$, an expander generator plant based on the 20 RPD-7.5/5.89 rotary piston engine allows to get $9 \ldots 89 \mathrm{MW}$ of energy each month. 


\section{REFERENCES}

[1] (2020) BP Statistical Review of World Energy. BP, 66 p.

[2] Corbeau, A.-S., Ledesma, D. (2016) LNG Markets in Transition: The Great Reconfiguration. Natural Gas Research Programme, $34 \mathrm{p}$.

[3] Belotskaya, E. D., Veselov, F. V., Galkin, Yu. V., Galkina, A. A., Geller, E. I. (2016) Prognoz razvitiya energetiki mira i Rossii 2016 [Forecast of energy development in the world and Russia 2016]. Moscow, INEI RAN ATsRF Publ., 195 p.

[4] Bumagin, G. I. (2007) Kriogennye mashiny [Cryogenic machines]. Omsk, OmGTU Publ., 216 p.

[5] Agababov, V. S., Koryagin, A. V., Andreev, A. R. (2004) Izmenenie pokazatelei kotel'nykh pri primenenii detandergeneratornykh agregatov [Changes in boiler house indicators when using expander-generator units]. Promyshlennaja jenergetika, № 7, pp. 38-44.

[6] Agababov, V. C. (2002) Osnovnye osobennosti primeneniya detander-generatornykh agregatov na TETs [The main features of the use of expander-generator units at CHP]. Energosberezhenie i vodopodgotovka, № 3, pp. $27-29$.

[7] Agababov, V. C. (2002) Metodika otsenki vliyaniya detander-generatornogo agregata na teplovuyu ekonomichnost' TETs [Methodology for assessing the impact of the expander-generator unit on the thermal efficiency of CHP]. Teploenergetika, № 5, pp. 48-52.

[8] Prilutskii, I. K., Arsen'ev, I. A., Molodov, M. A., Prilutskii, A. A., Shevtsova, A. I. (2015) Gazovyi porshnevoi detander nizkogo davleniya [Gas piston expander of low pressure]. Nauchnyi zhurnal NIU ITMO. Seriya "Kholodil'naya tekhnika i konditsionirovanie", № 3, pp. 1-14.

[9] Agababov, V. C., Koryagin, A. V. (2002) Opredelenie energeticheskoi effektivnosti ispol'zovaniya detander-generatornogo agregata $\mathrm{v}$ sistemakh gazosnabzheniya [Determination of the energy efficiency of using the expander-generator unit in gas supply systems]. Teploenergetika, № 12, pp. 35-38.

[10] Agababov, V. C., Koryagin, A. V., Khaimer, Yu. Yu., Loze, P. (2000) Ispol'zovanie detander-generatornykh agregatov v promyshlennosti [The use of expander-generator units in industry]. Energosberezhenie v Povolzh'e, № 3, pp. 89-91.

[11] Mironova, I. Yu. (2015) Perspektivy razvitiya rynka prirodnogo gaza v ATR: strategicheskie i institutsional'nye aspekty [Prospects for the development of the natural gas market in the APR: strategic and institutional aspects]. Ural'skoe vostokovedenie: mezhdunar. Al'manakh, Vol. 6, pp. 72-85.

[12] Bakhtizin, R. N, Dorozhkin, V. Yu., Teregulov, R. K., Mastobaev, B. N. (2016) Szhizhennyi prirodnyi gaz na sushe i v more. Proizvodstvo, khranenie, transport, regazifikatsiya [Liquefied natural gas onshore and offshore. Production, storage, transport, regasification]. Saint Petersburg, Nedra Publ, 428 p.

[13] Fal'man, A. G., Ageiskii, D. E. (2015) Perspektivy regazifikatsii SPG [Falman perspectives of LNG regasification]. Vestnik MAX, № 3, pp. 46-49.

[14] Fal'man, A. G., Ageiskii, D. E. (2016) Rabochee telo tsikla Renkina dlya utilizatsii kholoda regazifikatsii [The working body of the Rankine cycle for the utilization of cold regasification]. Vestnik Mezhdunarodnoi akademii kholoda, № 2, pp. 71-75.

[15] Akulov, K. A., Zemenkov, Yu. D., Gul'kov, A. N., Petryakov, V. A., Shipovalov, A. N. (2016) Gazovoe oborudovanie, pribory i armatura gazoraspredelitel'nykh setei i gazokhranilishch: uchebnoe posobie [Gas equipment, devices and fittings for gas distribution networks and gas storages: a tutorial]. Tyumen, TIU Publ., 317 p.

\section{BIBLIOGRAPHY}

[1] BP Statistical Review of World Energy. BP, 2020. 66 p.

[2] Corbeau A.-S., Ledesma D. LNG Markets in Transition : The Great Reconfiguration. Natural Gas Research Programm. 2016.34 p.

[3] Прогноз развития энергетики мира и России 2016 / Е. Д. Белоцкая и др. Москва : ИНЭИ РАН / АЦРФ, 2016.195 с.

[4] Бумагин Г. И. Криогенные машины. Омск : Изд-во ОмГТУ, 2007. 216 с.

[5] Агабабов В. С., Корягин А. В., Андреев А. Р. Изменение показателей котельных при применении детандер-генераторных агрегатов, Промылиленная энергетика. 2004. № 7. С. 38-44.

[6] Агабабов В. С. Основные особенности применения детандер-генераторных агрегатов на ТЭЦ. Энергосбережение и водоподготовка. 2002. № 3. С. 27-29.

[7] Агабабов В. С. Методика оценки влияния детандер-генераторного агрегата на тепловую экономичность ТЭЦ. Теплоэнергетика. 2002. № 5. С. 48-52.

[8] Газовый поршневой детандер низкого давления / И. К. Прилуцкий Научный журнал Санкт-Петербургского национального исследовательского университета информационных технологий, механики и оптики. Серия «Холодильная техника и кондиционирование». 2015. № 3. С. 1-14.

[9] Агабабов В. С., Корягин А. В. Определение энергетической эффективности использования детандер-генераторного агрегата в системах газоснабжения. Теплоэнергетика. 2002. № 12. С. 35-38.

[10] Использование детандер-генераторных агрегатов в промышленности / В. С. Агабабов и др. Энергосбережение в Поволжье. 2000. № 3. С. 89-91.

[11] Миронова И. Ю. Перспективы развития рынка природного газа в АТР: стратегические и институциональные аспекты. Уральское востоковедение : международный альманах. 2015. Вып. 6. С. 72-85.

[12] Сжиженный природный газ на суше и в море. Производство, хранение, транспорт, регазификация / Р. Н. Бахтизин и др. Санкт-Петербург : Недра. 428 с. 


\section{ЕНЕРГЕТИЧНЕ МАШИНОБУДУВАННЯ № З 2020}

[13] Фальман А. Г. Перспективы регазификации СПГ. Вестник Международной академии холода. 2015. № 2. С. 46-49.

[14] Фальман А. Г., Агейский Д. Э. Рабочее тело цикла Ренкина для утилизации холода регазификации. Вестник Международной академии холода. 2016. № 2. С. 71-75.

[15] Газовое оборудование, приборы и арматура газораспределительных сетей и газохранилищ : учебное пособие / К.А. Акулов и др. Тюмень : ТИУ. 317 с.

(C) О. С. Митрофанов, А. Ю. Проскурін Дата надходження статті до редакції: 11.08 .2020 Дата затвердження статті до друку: 21.08.2020 